\title{
Interaction Among Hormones or Peptides May Be Involved in Gastric Motor Physiology
}

\author{
Xiaohua Hou
}

Division of Gastroenterology, Union Hospital of Tongji Medical College, Huazhong University of Technology and Science, Wuhan, China

\author{
Article: The role of cholecystokinin 1 receptor in prolactin inhibited gastric emptying of male rat \\ Chang FY, Lu CL, Chen TS, Wang PS \\ (J Neurogastroenterol Motil 2012;18:385-390)
}

The manuscript, "The role of cholecystokinin 1 receptor in prolactin inhibited gastric emptying of male rat," is a well designed study. ${ }^{1}$ I would like to congratulate the authors for their excellent work. In the acute hyperprolactinemic rats, the authors found that prolactin inhibited the gastric emptying dose-dependently and increased the level of cholecystokinin (CCK). The selective CCK1 receptor antagonist restored the delayed gastric emptying induced by prolactin although it had no effect on gastric emptying, which suggested that prolactin worked via the CCK1 receptor. In the chronic hyperprolactinemic rats, similar increase of CCK level and delayed gastric emptying was also found. Previous studies have demonstrated the effect of prolactin on gastrointestinal motility in lactating rodent. ${ }^{2}$ Increases in gastric emptying and gastrointestinal transit correlated with lactation and plasma prolactin levels. In this study, the inhibited gastric emptying was found in hyperprolactinemic male rats, which suggested that the effect of prolactin differed by gender and species. This result may provide a guide for future study and clinical use. The reviewer has some comments: (1) The purpose of experi- ments with chronic hyperprolactinemic rats, I suppose, is to confirm that chronic and exogenous prolactin is also capable of inhibiting the gastric emptying via CCK. However, it has been reported that prolactin can stimulate the secretion of hormones such as testosterone etc. ${ }^{3}$ It is also demonstrated that the sexual hormones have the ability of regulating the gastric emptying. ${ }^{4}$ Administration of estrogen inhibits the rat gastric emptying while progesterone enhances the gastric emptying. Therefore, a further session including the CCK1 receptor antagonist should be investigated to confirm that the exogenous prolactin also act through the CCK. (2) As the authors mentioned, prolactin showed a reversed effect in lactating rats. For more reliable result presenting different effects of prolactin on gastric emptying in different genders, it is better to perform an additional experiment involving no-lactating female rats since the sexual hormones during lactation are completely different from non-lactating period and the hormones may have effect on gastric emptying, such as progestrone etc. ${ }^{6}$ (3) CCK is an important hormone for regulating the food intake and satiety sensation. ${ }^{7-9} \mathrm{CCK}$ induces reduction of

Received: September 28, 2012 Revised: October 3, 2012 Accepted: October 4, 2012

(c) This is an Open Access article distributed under the terms of the Creative Commons Attribution Non-Commercial License (http://creativecommons. org/licenses/by-nc/3.0) which permits unrestricted non-commercial use, distribution, and reproduction in any medium, provided the original work is properly cited.

*Correspondence: Xiaohua Hou, MD, PhD

Division of Gastroenterology, Union Hospital of Tongji Medical Univeristy, Huazhong University of Technology and Science, Wuhan 430022, China

Tel: +86-27-8572-6930, Fax: +86-27-8572-6930, E-mail: houxh@medmail.com.cn

Financial support: None.

Conflicts of interest: None. 
food intake dose-dependently and CCK1 receptor is involved in regulating caloric intake. In the experiments of chronic hyperprolactinemic rats, the author did not show whether there were any changes in the food intake and weight in the rats or not. If yes, it might enlighten some new use of prolactin, such as in obesity.

\section{References}

1. Chang FY, Lu CL, Chen TS, Wang PS. The role of cholecystokinin 1 receptor in prolactin inhibited gastric emptying of male rat. J Neurogastroenterol Motil 2012;18:385-390.

2. Chen TS, Doong ML, Wang SW, et al. Gastric emptying and gastrointestinal transit during lactation in rats. Am J Physiol 1997; 272(3 Pt 1):G626-G631.

3. Rubin RT, Gouin PR, Lubin A, Poland RE, Pirke KM. Nocturnal increase of plasma testosterone in men: relation to gonadotropins and prolactin. J Clin Endocrinol Metab 1975;40:1027-1033.

4. Gual O, Bozkurt A, Deniz M, Sungur M, Yeğen BC. Effect of sex steroids on colonic distension-induced delay of gastric emptying in rats. J Gastroenterol Hepatol 2004;19:975-981.

5. Chen TS, Doong ML, Chang FY, Lee SD, Wang PS. Effects of sex steroid hormones on gastric emptying and gastrointestinal transit in rats. Am J Physiol 1995;268(1 Pt 1):G171-G176.

6. Liu CY, Chen LB, Liu PY, Xie DP, Wang PS. Effects of progesterone on gastric emptying and intestinal transit in male rats. World J Gastroenterol 2002;8:338-341.

7. Donovan MJ, Paulino G, Raybould HE. CCK(1) receptor is essential for normal meal patterning in mice fed high fat diet. Physiol Behav 2007;92:969-974.

8. Woods SC. Gastrointestinal satiety signals I. An overview of gastrointestinal signals that influence food intake. Am J Physiol Gastrointest Liver Physiol 2004;286:G7-G13.

9. Gibbs J, Young RC, Smith GP. Cholecystokinin decreases food intake in rats. J Comp Physiol Psychol 1973;84:488-495. 